\title{
OFFICER PERFORMANGE AND COMPENSATION IN LOCAL BUILDING TRADES UNIONS
}

\author{
RONALD EHRENBERG and STEVEN GOLDBERG
}

$\mathrm{T}$ His paper presents estimates of the relatonship between the performance and compensation of local building trades union leaders. A growing literature has revived the common-sense notion that organizations should structure the compensation of both their employees and their executives 80 as to encourage them to take actions consist. ent with the goals of the organizations. One way to minimize the probability that executives will take actions contrary to the organization's goals is to tie their compensation to measures of their organization's performance.

This point is clearly relevant in profitmaking enterprises where shareholders' interests are best served by executives' striving

This study teats the hypothesis that the salary of a local buainess agent in the building trades is related to both the ability to pay of his local union and his own bargaining performance, the latter measured by a comparison of the wages he obtains for his local's members with the wages obtained for the members of other locals. Using pre. viously unpubliahed data for 670 locals in eleven crafts and sixtyeight citles, the authors find sub. stantial upport for their hypotheats.

Ronald Ehrenberg is Assoclate Professor of Rco. nomics and Labor Bconomics at Cornel] University and Steven Coldberg is a graduate student in eco. nomics at Northwestem Uniwersity. They are grate. ful to Jack Whiting for his research assistance and to Robert S. Smith for his comments on an earlier dratt of this paper-Eorros.

1See, for example, Armen Alchtan and Harold Demsetz, "Production, Information Costs, and Eco. nomic Organization," American Economic Review, Vol. 62, No. 4 (December 1972), pp. 777-95; and Gary Becker and George Stigler, "Law Enforcement, Malfeasance and Compensation of Enforcera," Joutr. nal of Logal studles, Vol. 8, No. I (January 1974), pp. 1-18. to maximize the firm's profits. Tying executives' compensation directly to their firm's profitability through stock options or bonus schemes is one strategy available to induce this behavior. ${ }^{2}$ Recent empirical evidence indicates that business firms do pursue such strategies."

It should be equally rational for public and private nonprofit organizations to tie their employees' or executives' compensation to the achievement of the organizations' goals, and a number of studies have documented that several types of nonprofit organizations do. University professors' com. pensation, for example, appears to be related to variables reflecting their contributions toward achieving the multiple goals of their institutions (research, teaching, and admin.

2Willam Baumol, Business Behavior, Value, and Growth (New York: Harcourt, Brace and World, 1967); Richard Cyert and James March, $A$ Behavioral Theory of The Firm (Englewood Cllfts, N.J.t Prentice-Hall, 1968); and Oliver B. Williamson, The Economics of Discretionary Behatior: Mana. gerial Objectives in a Theory of the Firm (Engle. wood cliffs, N.J.: Prentice-Hali, I967) all discuss objectives that executives may wish to puraue that conflict with maximizing firms' profits. By tying compensation to firms' profitability, the cost of pursuing these objectives is increased, thereby re. ducing the probability that executives will purate them.

asce Robert Masson, "Executive Motivations, Earn. inge, and Consequent Performance," Journal of Political Economy, Vol. 79, No. 6 (November/ December 1971), pp. 1278-98. Prevfous studles, such as Wilbur lewellan, Executive Compensalton in the Large Industrial Corporation (New York: National Bureau of Economic Research, 1968) and J. W. McGulre, J. S. Chiu, and A. O. Elbing, "Bxecutive Income, Sales, and Profits," American Economic Review, Vol. 52, No. 4 (September 1962), pp, 768-61, were less defintive on this point; their methodological approached, however, have been severely criticized by Masson. 
istrative activity). Similarly, it has been shown that the compensation of a number of categories of municipal government offcials (city managers and police and fire chiefs) is systematically related to several derived measures of their success in meeting municipal taxpayers' objectives. ${ }^{\circ}$

In this paper we extend the previous literature by seeking to ascertain if the compensation of a category of local build. ing trades union leaders-chief business agents-is related to their performance in office. That is, are these officers rewarded for taking actions consistent with their members' best interests? An analysis of this question is greatly complicated by the mul. tiplicity of tasks faced by local union offi. cers, especially business agents, and the existence of geographic and occupational interdependencies in collective bargaining in the building trades industry.

The plan of our paper is as follows: In the next section we consider the problems involved in attempting to measure the performance of union officers and suggest several proxy mensures. The third section outlines our empirical model of local union officers' compensation, discusses our data soutces, and presents some summary statistics calculated from the data. Our empirical estimates of the determinants of local union leaders' compensation, based upon a sample of records from 670 local unions representing eleven crafts in sixty-eight large cities, are presented in the fourth section. Finally, we offer some brief con. cluding comments.

Studies of the determinants of the com. pensation of local building trades union leaders have been conducted previously, but they have primarily been descriptive, twoway tabulations of local union leaders' compensation and local unions' character-

4David Katz, "Paculty Salaries, Promotions, and Productivity at a Large University," American $E_{c o}$. nomic Review, Vol. 63, No. 3 (June 1975), pp. 46977 , and John Slgfried and Kenneth White, "Finan. cial Rewards to Researcls and Teaching: A Case Study of American Economista," American Econamic Review, Vol, 63, No. 2 (May 1973), Pp. 309-15, are representative of this lifterature.

BGerald $S$, Goldstetn and Ronald $G$. Ehrenberg. "Bxecutlve Compensatlon in Municipailties," South. ern Economic Joumal, Vol, 48, No. 1 (July 1970), Pp. 987-17. istics (such as size) without any behavioral model. ${ }^{\circ}$ One previous study did provide a multivariate analysis of local union leaders' compensation.' Unfortunately, it was con. fined to a single geographic area, ignored the geographic and occupational interde. pendency of collective bargaining in the industry, and contained an estimating equation with a functional form that was, as explained below, misspecified.

\section{Measurement of Leaders' Performance}

Local building trades unions elect nu. merous officials, including some who are salaried. Typically each local elects a fulltime, salaried business agent who has primary responsibility for industrial relations in the union. ${ }^{8}$ One important function of business agents is to represent the local in its collective bargaining negotiations; others include representing the local before legal bodies, handling grievances of the local's members, directing strikes and boycotts, defending the jurisdiction of the local, and policing and enforcing provisions of contracts. Given these numerous tasks, any complete measure of a business agent's per. formance would necessarily have many dimensions. For the purpose of this paper, however, we focus on a single dimension: the level of compensation the business agent attains at the bargaining table for his local's members.

Gee Leon Applebaum, "Offer Turnover and Salary Siructure in Local Unions," Industrial and Labor Relations Review, Vol. 19, No. 2 (January 1966), pp. 224-90; Leon Applebaum, "A Comparison of Officer Turnover and Salary Structures in Local Unjons," Labor Law Journal, Vol. 20, No. 12 (December 1969), pp. 795-802; and Harry Blaine and Leon Applebaum, "Compensation and Turnover of Union Offcers," Industrial Retations, Vol. 14, No. 2 (May 1975), pp. 15(-57.

TBarry Bressler, "The Salaries of Union Officials with specife Reference to the Conetruction Indus. Iry," Economic and Business Bulletin, Vol, 24, No. 1 (Spring/Summer 1972), pp. 46-\$0.

This paragraph is based upon material found in Daniel Quinn Milla, Industrial Relations and Manpower in Construction (Cambridge, Mass.: M.I.T. Press, 1972); Van Dusen Kennedy and Wilma Rule Krauss, The Business Agent and His Union (Berkeley, Cellit: Institute of Industrial Relations, 1955); and George Stratus, Untons in the Building Trades (Buffalo, N.Y.: University of Buftalo Prest, 1958). 
Collective bargaining agreements in the building trades industry are typically nego. tiated for a local union for a single craft in a particular geographic area. Bargain. ing in the industry is notoriously interdependent, however, with local union mem. bers being concerned not only with the absolute level of their wages but also with their wages relative to the wages of other crafts in the same city and to the wages in their craft in other cities. ${ }^{10}$

It is not a priori obvious whether union members evaluate business agents' perform. ance with reference to percentage or abso. lute wage differentials. Therefore we spe. cify two sets of measures of business agents' performance for use in our empirical anal. ysis: (l) a set based upon percentage differ. entials: the journeyman wage scale for their particular local union relative to the aver-

-Exceptions to this rule are national or regional agreements covering the construction or installa. tion of pipelines, sprinkler systems, and elevators, with local union wages in the last case being re. lated to the wages of other local crafts in the area by a fixed formula. Also, several crafts in other sectors of the Industry often engage in regional bargaining, often by metropolitan area, in the west. em section of the country. Sce Millo, Industrial Relations and Manpower in Construction, for de. talls. We attempt to take account of these exceptions in our empirical work below (sec footnote 22).

10For elaborations on this point, see Gordon Ber. tram and Sherman Maisel, Industrial Relations in the Construction Industry (Berkeley, Callf:; Institute of Industrial Relations, (955); Margaret Chandler, "Craft Bargaining" in John Dunlop and Neal Chamberlain, eds., Frontiers of Collective Bargaining (New York: Harper and Row, 1967); Johnt Dunlop, "The Industrial Relations System in Con. struction" in Arnold Weber, ed., The Structure of Collective Bargaining (Chicago: Unjversity of Chi. cago Press, 1961); Alan Gustman and Martin Segal, "Wages, Wage Supplements, and the Interaction of Dargalns in the Construction Industry," Industrial and Labor Relallons Review, Vol, 25, No. 2 (Janu. ary 1972), pp. 179-86; Alan Gustman and Martin Segal, "The Skilled.Unskilled Wage Dilferential in Construction," Industrial and Labor Relations $R e$ view, Vol. 27, No. 2 (January 1974), pp. 179-86; Kenneth McCaffree, "Regional Labor Agreements in the Construction Industry" Industrial and Labor Relations Review, Vol, 9, No. 4 (July 1956), pp. 505-609; Mills, Industrial Relations and Manpower in Construction; Albett Rees, "The Conatruction Industry Stabilization Committee: Implications for Phase II," Brookings Papers on Economic Activily, No. (Washington, D.C.: The Brookings Institution, 1971), pp. 760-68; and Strauss, Unions in the Building Trades. age journeyman wage scale in the city $\left(R W_{1}\right)$ and the journeyman wage scale for their local relative to the average national journeyman wage in the craft $\left(R W_{2}\right) ;(2)$ a set based upon absolute differentials: the journeyman wage scale for their particular local union minus the average journeyman wage scale in the city $\left(D W_{1}\right)$ and the journeyman wage scale for their local minus the average national journeyman wage in the craft $\left(D W_{2}\right)$.

Our use of the these measures indicates our belief that union members are more concerned with the level of their relative position at a point in time than with recent changes in their relative position."1 Put another way, our belief is that unions whose members' wages are relatively high will not penalize their leaders if they attain smaller than average percentage or absolute wage gains in a given year because of the members' awareness of the difficulties involved in trying to maintain an "outlier" pasition (the phenomenon of regres. sion to the mean).

\section{An Empirical Model of Compensation}

The objective of this paper is to relate local union leaders' compensation to their performance. Broadly defined, a leader's compensation may be increased in two ways: first, through increases in monetary payments or fringe benefits; second, through being retained in office. Business agents and other officials are political figures who must stand for reelection periodically (at one- to three-year intervals in the case of business agents) and thus local member satisfaction with their performance may be reflected by their not being voted out of office as well as by increases in their com. pensation. Unfortunately, because of the cross-sectional nature of our data, we are restricted to considering only the impact of performance on monetary payments to officers. ${ }^{12}$ Hence the results presented below

11If the opposite were true, the relevant perform. ance measurcs would be the changes or percentage changes in $R W_{1}$ and $R W_{2}$ (or $D W_{1}$ and $D W_{2}$ ).

19Research on the determinants of local unton officials' tenure is currently being conducted by a Ph.D. candidate under Gien Cain's direction at Wlsconsin. 
tunderstate the total incentive effect for performance that business agents face.

Our basic hypothesis is that local union leaders' compensation is related both to measures of the union's ability to pay and to measures of their agents' performance. Empirically, this is reflected in cross-section estimating equations of the form:

and

$$
\begin{aligned}
S_{i j}= & \beta_{0 i}+\beta_{11} X_{1 i j}+\beta_{2 i} X_{i j} \\
& +\beta_{8 i} X_{9 i j}+\beta_{1 i} R W_{1 j} \\
& +\beta_{v i} R W_{2 i}+\epsilon_{t j}
\end{aligned}
$$

$$
\begin{aligned}
S_{i j}= & \alpha_{0 i}+\alpha_{1 i} X_{1 i j}+\alpha_{2 i} X_{3 i j} \\
& +\alpha_{3 i} X_{3 i j}+\alpha_{4 i}\left(R W_{1 i j}\right)\left(X_{2 i j}\right) \\
& +\alpha_{w i}\left(R W_{1 i j}\right)\left(X_{2 i j}\right)+\epsilon_{i j}
\end{aligned}
$$

where:

$s_{i j}=$ chief business agent's salary in craft $i$ in city $j$;

$X_{1 j}=$ total annual local union dues collected in craft $i$ in city $j ;$

$X_{91 j}=$ total "journeymen-equivalent" members in the union representing craft $i$ in city $j ;^{12}$

$X_{M}=$ total net assets of the local union representing craft $i$ in city $j j^{14}$

$R W_{1 i f}=$ journeyman wage scale in craft $i$ in clty $j$ relative to the average journeyman wage scale in city $j$;

$R W_{2 i}=$ journeyman wage scale in craft $i$ in city $j$ relative to the average

18" Journeymen equivalent" memliers is calculated by dividing reported average monthly dues recelved by the local by monthly dues per journeyman. The level of dues often differs for apprentices, helpers, fourneymen, and retirees; as the perceitage composition of a unlon's members across these classes varles, our estimate will also vary.

1+The net assets of the American labor move. ment were estimated to be about $\$ 2.25$ billion or $\$ 124$ per member in 1989 by leo Troy, "The Finances of Amertcan Unions, 1962-69," Explora. tows in Economic Research, Vol. 2, No. 2 (Spring 1975). Most unions keep the majority of their assets in the form of cash or liquid assets to maintain liquidity in case of a strike. The mafor source of revenue for lacal unions is of course the flow of local memberahip dues. The mean per member level of asces in our sample varted across crafts from about $\$ 00$ to $\$ 100$ and the mean level per local from about $\$ 12,000$ (marble setters) to $\$ 14,000$ (plumbers), Troy's figures include assets heid by natlonal unions, but our figures refer only to local union assets national journeyman wage scale in craft $i$

$D W_{1 i f}=$ journeyman wage scale in craft $i$ in city $j$ minus the average journeyman wage scale in city $j$; and

$D W_{9 i j}=$ journeyman wage scale in craft $i$ in city $j$ minus the average national journeyman wage scale in craft $i$.

Variants of Equations 1 and 2 in which the "absolute differential" performance measures $\left(D W_{t}\right.$ and $\left.D W_{8}\right)$ replace the "percentage differential" measures $\left(R W_{1}\right.$ and $\left.R W_{2}\right)$ are also specified but not shown (Equations 8 and 4). Two features of these equations should be noted. First, total annual dues $\left(X_{1}\right)$, total "journeymen-equivalent" members $\left(X_{y}\right)$, and total net assets $\left(X_{s}\right)$ of the local union are included as measures of the local union's ability to pay its officers. In a more complete model all of these ability-to-pay variables might be considered endogenous, as they are at least partially determined by previous and current wage scales of union members and the number and duration of strikes conducted by the local union in the past. Since we lack data on their determinants, however, these variables are treated as exogenous for the purpose of this study.16 As might be expected, these variables are strongly correlated across locals within a craft and it is difficult to estimate their independent effects precisely.

Second, Equation 2 specifies that the marginal impact of performance on the level of union leaders' compensation is a function of the size of the local union. That is, it is hypothesized that the magnitude of the increase in salary a business agent receives if he achieves a given level of performance will be larger in a large than a small local union, since the larger the union, the larger the total increase in earnings received by the members. Although this seems like a plausible hypothesis, one might also argue that the impact of performance is invariant

\footnotetext{
18 An interesting extension of the present atudy would be to consider their determinant: explicitly. One might develop a model of the supply and demand tor union servlces, for example, and derive a reduced torm eximating equation for the market clearlng price (such as monthly duen per man). Sadly, our data do not permit us to do this.
} 
to scale.16 Hence, we also estimate Equation 1 in which "reward for performance" does not vary with union size.

Our analysis is based upon cross-section data for eleven crafts in sixtyeight cities in 1971. The analysis was restricted to a single year's cross section and a subset of the building trades crafts because of constraints on the time we had available to copy data from unpublished union financial reports on file in Washington, D.C. We obtained information on monthly dues per journeyman, net local union assets, total annual dues collected, and the chief business agent's salary from LM.2 and LM-s union financial reports on file with the Office of Labor-Management and Welfare Pension Reports, Labor-Management Services Administration, U.S. Department of Labor. The cities included in the sample were those large cities for which data on local union journeyman wage scales, average journeyman wage scales by city, and average national journeyman wage scale by craft were available for the same period in published sources, ${ }^{17}$

Table 1 presents means and standard de.

10Bressler, "The Salaries of Union Oficlals," for example, specified that the marginal impact of an viations for the salaries of the chief business agents in the local unions in our sample. The mean levels of annual com. pensation vary from almost $\$ 6,000$ to slightly over $\$ 20,000$. This variation reflects not only intercraft differences in the average size of locals, but also substantial variation within a craft in both the level and per-member values of chief business agent's salary. ${ }^{1 \mathrm{t}}$

\section{Bconometric Results}

Equations 1 and 2 and their variants, which replace $R W_{1}$ and $R W_{2}$ by $D W_{1}$ and $D W_{2}$, were estimated separately for each craft for a sample of 670 local unions, each having a paid chief business agent. The specific results varied across crafts but in general most of the regression coefficients, especially those for the performance meat-

\footnotetext{
Increase in the union wage scale on officers' salaty did not depend upon the size of the local.

17U.S. Bureau of Labor Statiotics, Union Wages and Hours: Dullding Trades, July $I, 1971$, Bulletin No. 1747 (Washington, D.C.: G.P.0., 1972).

18which officer filled the role of chief business agent is not always obvious from the titles reported on forms $L M-2$ and $L M-8$. When there was con. fusion, we used the figure for the official who had the largest reported salary.
}

Table 1. Selected Characteristics of a Sample of Local Unions, 1971.

\begin{tabular}{|c|c|c|c|}
\hline Graft & $\begin{array}{l}\text { Sample Size } 1 / \text { Mean } \\
\text { Members per Local }\end{array}$ & $\begin{array}{c}\text { Moen Annual Salary } \\
\text { of Chief Butriness } \\
\text { Agents } 6\end{array}$ & $\begin{array}{c}\text { Mean Annual Salary } \\
\text { of Chif Business } \\
\text { Agcots/Namber } \\
\text { of Mombers b }\end{array}$ \\
\hline $\begin{array}{l}\text { Boilermakert } \\
\text { Lathers } \\
\text { Roofers } \\
\text { Asbestos workers } \\
\text { Bricklayern } \\
\text { Ironworkers } \\
\text { Plasterers } \\
\text { Marble setters } \\
\text { Cement masons } \\
\text { Elevator constructors } \\
\text { Plumbers } \\
\text { Total Sample }\end{array}$ & $\begin{array}{c}80 / 864 \\
40 / 261 \\
48 / 404 \\
39 / 538 \\
86 / 708 \\
105 / 1,307 \\
78 / 319 \\
44 / 995 \\
24 / 1,802 \\
42 / 1,431 \\
84 / 776 \\
670 / 829\end{array}$ & $\begin{array}{c}16,818(9,736) \\
6,602(6,922) \\
14,571(13,574) \\
15,616(11,170) \\
11,947(10,633) \\
14,602(7,642) \\
5,787(7,166) \\
15,519(9,532) \\
17,110(7,197) \\
20,566(12,941) \\
19,284(8,020) \\
12,244(10,368)\end{array}$ & $\begin{array}{c}712.04(27.38) \\
53.46(51.63) \\
113.91(902.85) \\
75.67(202.64) \\
25.97(30.49) \\
22.99(34.07) \\
27.42(43.11) \\
37.29(48.55) \\
45.99(92.08) \\
47.88(54.46) \\
61.80(162.41) \\
42.17(118.95)\end{array}$ \\
\hline
\end{tabular}

- Number of local unions in sample. If more than 68 locals are included in the sample for a craft, this indicates the craft is represented by more than one local in some cities.

- Standard deviations are in parentheses.

Sosref; Authore' calculationa from LM-2 and LM-3 reports filed with the Office of Labor-Management and Welfare Penston Reports, Labor-Management Services Administration, U.S. Department of Labor. 
ures, were not statistically significant. This was due to both the small number of dogrees of freedom for some crafts and the presence of multicollinearity among the ability-to-pay variables within each craft.

In an attempt to alleviate these prob. lems, Equations 1 and 2 and their variants were reestimated with all of the observa. tions pooled into one sample in four different manners: (a) all coefficients constrained to be the same across crafts, (b) all coefficients except the intercept terms constrained to be the same across crafts, (c) all coeffi. cients except the intercept terms and the coefficient of $R W_{3}$ (or $\left.D W_{2}\right)$ constrained to be the same across crafts, and (d) all coeff. cients except the intercept terms and the coefficients of $R W_{1}$ and $R W_{2}$ (or $D W_{1}$ and $D W_{2}$ ) constrained to be the same across crafts. Based upon the residual sum of squares from these equations, formal $F$ tests were conducted to see which, if any, of the above restrictions do not significantly re. duce the explanatory power of the model.

These tests indicated that the restrictions imposed in (c) did not significantly reduce the explanatory power of the model as compared to the unconstrained (separate equation for each craft) case. Furthermore, the restrictions imposed in (c) did not significantly reduce the explanatory power of the model as compared to case (d). However, requiring that the coefficient of the withincraft performance measure be constant across crafts (cases (a) and (b)) did significantly reduce the explanatory power of the model as compared to the unconstrained case. Consequently, we conclude that pooling the data across crafts is permissible if done as in case (c) and in Table 2 we pre. sent estimates of Equations 1 and 2 and their variants, which replace $R W_{1}$ and $R W_{2}$ by $D W_{1}$ and $D W_{2}$ (Equations 8 and 4).

Pooling the data substantially improves the precision of our estimates. As expected, total dues and net local assets tend to be significantly related to chief business agents' salaries. The local union's wage scale,

10The insigniffcant coefficients obtained for the number of "full-time equitralent" members may be due to meaurement error in this varlable (bee (ootnote 18). however, relative to (or minus) the average wage scale of all crafts in the city is not a significant determinant of chief business agents' salaries in any specification. ${ }^{* 0}$

Focusing on the adjusted coefficients of determination $\left(\bar{R}^{2}\right)$, it is quite clear that Equation 2, which utilizes a percentage differential performance measure and pos tulates that the impact of performance on local union leaders' salary is proportional to the size of the local, is the preferred specification,"st For this specification, the coefficient of the withincraft performance measure $\left(R W_{2}\right)$ is positive, as predicted, in ten of eleven cases and statistically significant for five of the crafts. Moreover, similar patterns can be observed for the withincraft performance measures in the lesspreferred Equations 1, 3, and 4. Taken together, these estimates provide initial evidence that performance in office influences local building trades leaders' compense. tion. $*$ ?

200 ne possible explanation for the poor perform. ance of this vattable is that the use of the average building trades journeyman wage scale in the city in the denominator may be a misspecification. That is, the denominator will vary across ctties, even it each bullding trade's journeyman wage ts the same in all cities, simply because the occupational mix of journeymen varies across clites. This suggesta that either a fixed weight index or the use of a single craft' wage as a base might have been preferable. Unfortunately, data on building trades em. plopment levels by occupation and city are not available to use in constructing such an index and it was not clear, in the latter case, what the appro. priate base wage craft would have been. The une of a simple average acrows the eleven cratis in a city it an alternative to our approach; however, preliminary experiments with this measure at early stages in our research did not yield significantly different results.

91 Bquations were also estimated in which $R W_{1}$, $R W_{9}, R W_{1} \cdot X_{2}$, and $R W_{3} \cdot X_{1}$ appeared. Howewer, formal $\mathrm{P}$ tests indicated the inclusion of $R W_{1}$ and $\boldsymbol{R} \boldsymbol{W}_{2}$ did not significantly improve the explanatory power over Equation 2.

owe noted in footnote 9 that regional bargaining occurs in some crafts in the West. To sec if including weatern citles dintorted our estimates, we eliminated sixteen westem cities from our sample and reestimated Bquation 2. Eellmates obtalned from this reduced sample differed only manginally from those found in Table 2 and hence are not pro. sented here. We also noted prevlously the unique bargaining framework under which the wages of elevator contructors are tied to the wage sciles of other crafto in the area. The siguificant pertormance 
Table 2. Chief Business Agent Salary Equations: Pooled Sample--

(absolute value t-statistics)

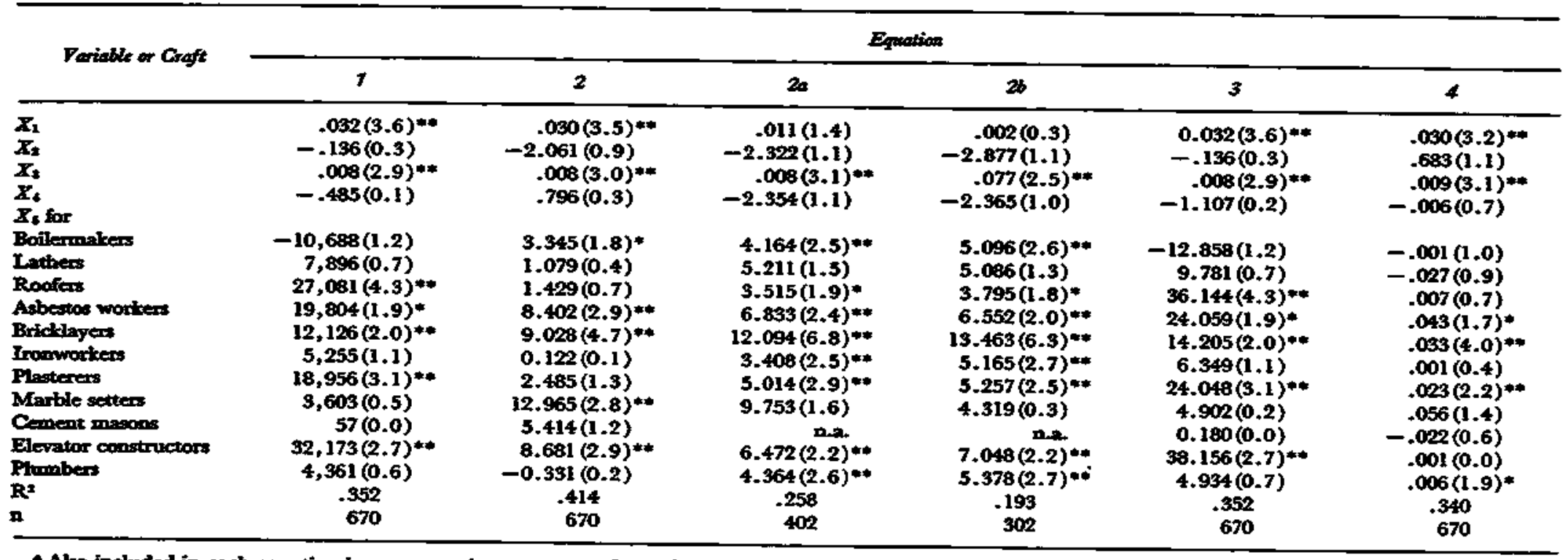

- Also included in each equation is a separate intercept term for each craft.

$X_{1}=$ total amnual ducs;

$X_{2}=$ number of "journeymen-equivalent" members;

$X_{7}=$ total net assets;

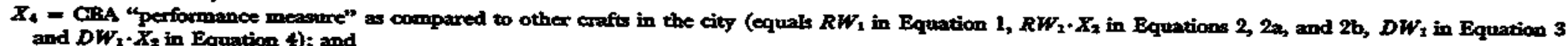

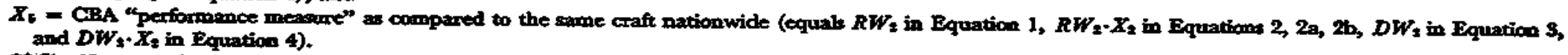

- Stignificant at the .05 level. 
A possible objection to this interpretation of our results is that the $R W_{2}$ variable may measure primarily the opportunity cost faced by the business agents; that is, it may indicate only how much they could earn as journeymen in their own trades and cities. If this objection were correct, $R W$, would be interpreted as a supply side vari. able; higher values would imply the need for higher salaries to hold business agents in their positions, and the $R W_{4}$ coefficient would tell us nothing about the relationship between business agents' performance and their rewards. In our view, the growing professionalization of union officers suggests that returning to the ranks is not an option that the majority of business agents seriously consider. Nevertheless, we attempted to test for the importance of this altemative hypothesis by reestimating Equation 2, using the pooled data but restricting ourselves to two subsamples of business agents who earn at least $\$ 10,000$ and $\$ 15,000$ respectively. Presumably, the elimination of the lower paid, perhaps part-time, officials from our sample sub. stantially reduced the probability that the $\boldsymbol{R} W_{2}$ variable was capturing supplyside effects.

Estimates for the subsample of business agents who earned at least $\$ 10,000(\$ 15,000)$ in 1971 are presented as Equations 2a (2b) in Table 2; these estimates tend to strengthen our argument. For both of the samples, all ten of the $R W_{2}$ coefficients are positive.2 Moreover, the elimination of the low-paid business agents increases the precision of the coefficients; eight are now statistically significant at the .05 level in both samples.

To get an idea of the magnitudes of these relationships, we have calculated and report in Table 8 the absolute and percentage increments in salary for local union leaders when the journeyman wage scale in

coefficlenta for this craft In Table 2 sugsest that union leaders in this craft get rewarded for the performance of union leaders in other crafta in their area.

89Cement masont are not Included in either of these subsamples as the restrictions left too few observationa for this craft to obtain any meaningtul results (orly twenty-four cement masons' localo were included is the orlginal ampie).
Table 3. Increment in Salary for Chief Business Agents Who Achieve Journeymen Wage Scale 10 Percent Above National Average Journeymen Wage Scale in the Craft. (Absolute Increment/Percentage Increment)

\begin{tabular}{|c|c|c|c|}
\hline Craft & $\begin{array}{c}\text { All Losals } \\
\text { (Eguation 2) }\end{array}$ & $\begin{array}{l}\text { Locals With } \\
\text { CBA Salary } \\
\geq \text { Jro,000 } \\
\text { (Equation 20) }\end{array}$ & $\begin{array}{c}\text { Locals Wath } \\
\text { CBA Solary } \\
\geq \$ 15,000 \\
\text { (Eguation } 26)\end{array}$ \\
\hline $\begin{array}{l}\text { Boller- } \\
\text { maken }\end{array}$ & $299 / 4.2^{\circ}$ & $360 / 5.2 *$ & $440 / 6.4^{\circ}$ \\
\hline Lathers & $28 / 0.4$ & $136 / 2.0$ & $133 / 2.0$ \\
\hline Roofers & $58 / 0.4$ & $142 / 0.9$ & $153 / 1.0^{\circ}$ \\
\hline $\begin{array}{l}\text { Abestos } \\
\text { worken }\end{array}$ & $452 / 2.9^{\circ}$ & $368 / 2.9 "$ & $352 / 2.2 \bullet$ \\
\hline Bricklayen & $689 / 5.4^{\circ}$ & $856 / 7.1^{4}$ & $953 / 7.9$ \\
\hline $\begin{array}{l}\text { Iron- } \\
\text { workers }\end{array}$ & $16 / 0.1$ & $398 / 2.7$ & $675 / 4.6^{\circ}$ \\
\hline Plasterera & $79 / 1.4$ & $160 / 2.74$ & $168 / 2.9^{\circ}$ \\
\hline $\begin{array}{l}\text { Marble } \\
\text { setters }\end{array}$ & $1,290 / 8.3^{a}$ & $970 / 6.2$ & $429 / 2.7$ \\
\hline $\begin{array}{l}\text { Cement } \\
\text { masons }\end{array}$ & $976 / 5.7$ & $\rightarrow$ & -+ \\
\hline $\begin{array}{l}\text { Elovator } \\
\text { con- } \\
\text { itructors }\end{array}$ & $1,242 / 6,0^{\circ}$ & $926 / 4.5 \bullet$ & $1,009 / 4.9^{\circ}$ \\
\hline Plumbers & $-26 /-0.2$ & $338 / 2.5^{\circ}$ & $417 / 3.1$ \\
\hline
\end{tabular}

- The eatimated coefficient uposs which this estimate was based was significantly different from zero at the .05 level (onertailed teat).

- Insufficient obecrvations to be included in the sample.

a craft is 10 percent above the national average journeyman wage scale in the same craft. Three sets of estimates are presented, based upon the estimated coefficients from Equations 2, 2a, and $2 \mathrm{~b}$ respectively. The estimates are calculated at the mean mem. bership level and chief business agent salary level in local unions in the craft. The implied absolute increment in the chief business agent's salary ranges between $\$ 0$ and $\$ 1290$ in the first set and about $\$ 180$ to $\$ 1000$ in the last two. These correspond to percentage increments in the range of 0.0 to 8.8 and 0.9 to 7.9 percent respectively. Hence, business agents who achieve relative wage gains for their members do 
appear to be rewarded quite well for their efforts, 24

\section{Qualifications and Conclusion}

This paper has presented estimates of the relationship between several proxy measures of performance and compensation of local building trades union leaders. Although the evidence is not totally unam. biguous, it does appear that chief business agents' salaries are increased when their members' wage scales are raised relative to the national average union wage scale for the craft-and therefore that local building trades union leaders are rewarded for this dimension of their performance. Rather surprisingly, however, the level of the members' wages relative to the wages of other building trades union members in the city does not appear to influence the officers' compensation measures. As sug. gested earlier (in footnote 20), this result may be due to an error-in-variables problem. Or it may reftect the following; An increase in the average wage in a city, ceteris paribus, might lead to an increase in leaders' salaries for cost-of-living reasons, even though measured performance might actually decline-once again indicating that the coefficient of the within-city performance measure might be biased downwards. Attempts were made to test this conjecture by including the average building trades union wage scale in the city as a separate independent variable in our analysis, but severe collinearity problems prevented us from obtaining any meaningful results.

One might argue that our results indi. cate only that there exists a rigid internal wage structure within each local union in which the wages of union leaders are specified as multiples of the journeymen wage scale. Indeed, recently the bricklayers' union voted to tie future wage gains of their national leaders to the members' wage

sWe also attethpted to arcertain whether our esilimated absolute and percentage impacts were cor. related with the mean level of officer compentalion or per-member compensation in the crats. Our roal was to see if in crafts in which leadeis had the Breatest incentive to perform, thetr salarles tended to bo higher. Unfortunately, with only eteven ob. cervations we could not obtain atrong evilence on this polnt. scale gains. ${ }^{26}$ Such schemes do have the effect of giving union leaders incentives to push for higher wage scales for their mem. bers, however, and hence do not contradict the argument we have presented here.

We must emphasize that due to the limited nature of the data available to us, our results should be viewed only as a sug. gestive first effort. It is clear that we were forced to omit a number of variables that might potentially bias our results. Tenure in office (itself endogenous), for example, reflects cumulative performance over a number of years and we might reasonably expect recently elected business agents to be paid less than experienced ones. In addi. tion, our single year's cross-sectional analysis cannot capture fully the lags that may exist between officers' salaries and perform. ance. Including lagged values of perform. ance, say $R W_{1}$ and $R W_{1}$ for the previous year, would probably not fully solve this problem because the lag structure may vary across crafts or locals within a craft. Even if the lag structure did not vary, since contracts vary in length and are negotiated on a staggered basis, our estimated coeff. cients are unlikely to capture fully the true relationship between performance and compensation.

In addition to trying to take account of the above problems, the logical extensions of our analysis are two fold. First, given enough resources, one could obtain timeseries data from the Labor Department for a subset of local unions and estimate for which locals (if any) the change in union leaders' compensation was related to the change in their measured performance. One could then test whether union wage scales increased most rapidly in those locals that did tie their leaders' salaries to perform. ance. Second, one could test whether local union leaders' temure in office and probability of being reelected to office are related to their performance. Together, these extensions should provide strong evidence as to whether the compensation of local build. ing trades union officials is currently structured rationally, from the union members' viewpoint. Our results tentatively suggest that it is.

os See AFL.ClO News, Washington, D.C., Septem. ber 27. 1975. 